J. Perinat. Med. 9 (1981) 145

\section{Oxytocinase versus estriol for the assessment of fetal well-being}

\section{Blum}

Department of Obstetrics and Gynecology, Hasharon Hospital, Petah-Tiqva, and Tel Aviv University Medical School, Israel
The assessment of the normal and pathological evolution of a pregnancy is possible due to the electronic and biochemical monitoring methods available. Among the numerous biochemical methods we have chosen two, more important tests: Urinary estriol $\left(E_{3}\right)$, a hormone produced by the fetoplacental unit, and cystine aminopeptidase (CAP), an enzyme of placental origin.

The aim of the present study was to show the advantage of these tests not only for the diagnosis of the fetal well-being, but also as an additional help in taking immediate obstetrical decisions, in cases of fetal distress, purpose that may be attained by serial serum CAP tests. One cannot obtain the same results by the examination of urinary $E_{3}$, one of the reasons being the lowering effect of ampicillin on estriol levels, and another one, the compartmentation of estriol in the maternal circulation.

At the same time, we tried to interprete the enterohepatic circulation of $\mathrm{E}_{3}$ by examining the urinary estriol during puerperium in women given or not an antibiotic treatment.

\section{Material and methods}

In a group of 45 healthy primiparae between 22 and 36 years of age, with normal term pregnancy, we have determined the serum CAP and urinary estriol levels in 24-hour samples collected during the prenatal visit made between the 37 th week and delivery. Of the 45 women examined, in 26 the pregnancy terminated by cesarean section, the indication being cephalopelvic dysproportion, acute fetal distress, or breech presentation in a primipara. This group of 26 women served as study group.

Urinary estriol and serum CAP levels were normal in all women before the cesarean section. According to whether the patient received or not prophylactic ampicillin after the cesarean section, she was assigned to one of the 2 equal groups of 13 patients each. The indication for prophylactic treatment administration was the necessity to prevent postpartum morbidity in a group of patients at risk (multiple vaginal examinations, internal fetal monitoring, etc.).

In the two groups of patients the urinary estriol and the serum CAP were examined 48 hours after delivery. The estriol was tested in 24hour urine collections, according to the method of BROWN et al. [8], the results being given in $\mathrm{mg} / 24 \mathrm{~h}$. The CAP activity was determined by hydrolysis of $\mathrm{L}$ cystine-di- $\beta$-naphthylamide by CAP, and colorimetric measurement of liberated $\beta$-naphthylamine (5).

Reagents: The substrate solution consisted of 135 $\mathrm{mg}$ of L-cystine-di- $\beta$-naphthylamide dissolved in $50 \mathrm{ml}$ of $0.012 \mathrm{~N} \mathrm{HCl}$ and $50 \mathrm{ml}$ of distilled water. The buffer consisted of $69.9 \mathrm{ml}$ of $0.1 \mathrm{~N}$ sodium barbital mixed with $21.1 \mathrm{ml}$ of $0.1 \mathrm{~N} \mathrm{HCl}$ and adjusted to a $\mathrm{pH}$ of 7.9. The substrate and buffer are stable when stored at $4{ }^{\circ} \mathrm{C}$. 
Procedure: Serum, $0.6 \mathrm{ml}$, was diluted with $0.9 \mathrm{ml}$ of distilled water and $3.0 \mathrm{ml}$ of the buffer solution. A $0.75-\mathrm{ml}$ sample was placed in each of three test tubes - two duplicates and one blank. Substrate, $0.25 \mathrm{ml}$, was added to each tube and the test samples were incubated at $37^{\circ} \mathrm{C}$ for $2 \mathrm{~h}$. The reaction was stopped by the addition of $1.0 \mathrm{ml}$ of $10 \%$ trichloroacetic acid. Supernatant, $1.0 \mathrm{ml}$, obtained by centrifuging the samples at $3000 \mathrm{~g}$ for $15 \mathrm{~min}$, was transferred to clean tubes. An acetone-HCl solution, $2.5 \mathrm{ml}$, and $1.0 \mathrm{ml}$ of $0.1 \%$ sodium nitrite solution were added to each tube. After exactly $3 \mathrm{~min}, 1.0 \mathrm{ml}$ of $0.5 \%$ ammonium sulfamate solution was added and the solutions were mixed and allowed to stand for $2 \mathrm{~min}$. Then, $2 \mathrm{ml}$ of $0.05 \% \mathrm{~N}-(1$-naphthyl)-ethylenediamine dihydrochloride were added and the tubes were permitted to stand for $40 \mathrm{~min}$, for maximum color to develop. The results are given in OD units read at $565 \mathrm{~nm}$ against a blank solution.

\section{Results}

In the patients not receiving antibiotic treatment, a decrease in the urinary estriol was observed $48 \mathrm{~h}$ after delivery, until an average of $5.55 \mathrm{mg} / 24 \mathrm{~h}$. In the patients treated by ampicillin the decrease in the urinary estriol was more drastic, the level reaching approximately that of the normal menstrual cycle, i.e. an average of $1.62 \mathrm{mg} / 24 \mathrm{~h}$.

The serum CAP level was not affected by the antibiotic treatment. The mean level of this enzyme was of 134.0 OD units, $48 \mathrm{~h}$ after delivery, corresponding to the level recorded during the second trimester of a normal pregnancy. The serum halflife of CAP continued to be decreased, but still existent, until one month after delivery (Figs. 1,2).

The statistical comparative results of the postpartum examination, calculated according to the "Students' $t$ test", may be seen in the Tab. I.

\section{Comment}

Clinicians have long sought a single chemical analysis that would give current and precise information about the condition of the fetus in utero.

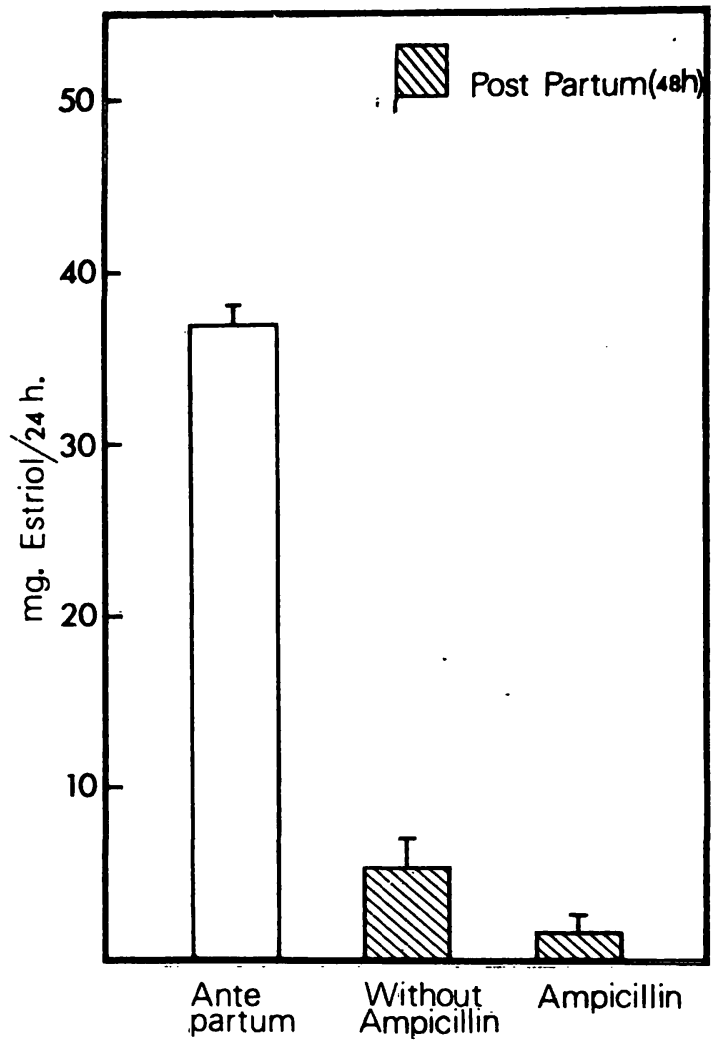

Fig. 1. Urinary estriol levels before and $48 \mathrm{~h}$ postpartum in the two groups of patients, without and with ampicillin treatment.

Tab. I. Mean values of urinary estriol (mg/24 h) $48 \mathrm{~h}$ postpartum in the two groups of patients.

\begin{tabular}{lll}
\hline Patients & No. of cases & Mean value \pm SD \\
\hline $\begin{array}{l}\text { Not receiving } \\
\text { antibiotic treatment }\end{array}$ & $5.55 \pm 1.56$ \\
$\begin{array}{l}\text { Receiving ampi- } \\
\text { cillin treatment }\end{array}$ & 13 & $1.62 \pm 0.76$ \\
\hline
\end{tabular}

t value $=8.19$

$\mathrm{p}<0.01$, significant

Hormones and enzymes were used, but no one determination can provide such information. As it has been shown by many authors such as RADO et al. [14], LUUKKaINEN [13] and ADLERCREUTZ et al. [1] $\mathrm{E}_{3}$ precursors are produced by the fetal adrenal cortex. At least $90 \%$ of the precursors are produced mainly as sulfates of dehydroepiandrosterone (DHEAS) and 16- $\alpha$-hydroxy dehydroepiandrosterone (16- $\alpha-\mathrm{OH}$ DHEAS). Much 


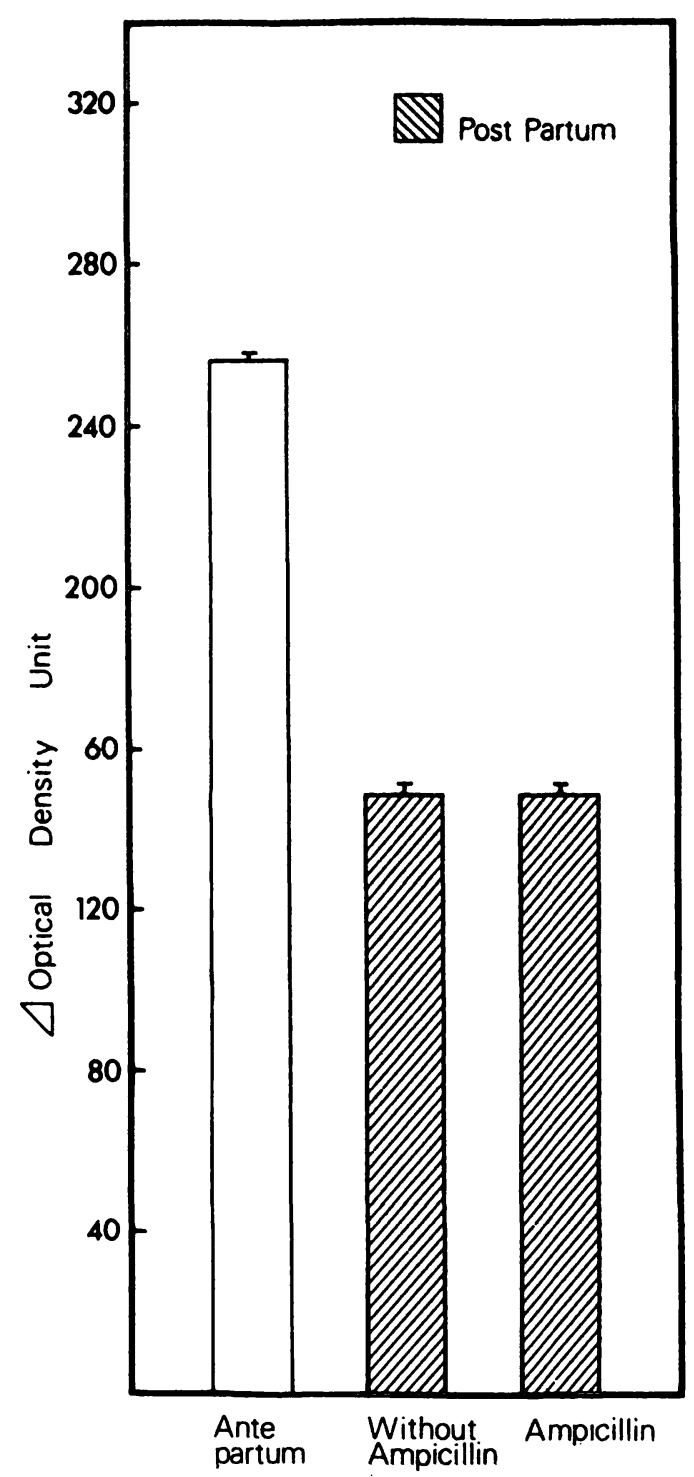

Fig. 2. Serum CAP levels before and $48 \mathrm{~h}$ after delivery in the two groups of patients, without and with ampicillin treatment.

of the DHEAS is converted to 16- $\alpha-\mathrm{OH}$ DHEAS in the fetal liver. Conversion of the precursors to $\mathrm{E}_{3}$ is entirely a placental function. Consequently the maternal and urinary estrogens reflect the functional status and well-being of the feto-placental unit. As already reported in the literature $[9,12]$ the $E_{3}$ enters from the feto-placental unit into the maternal circulation and it is afterwards distributed to the different compartments such as maternal plasma, interstitial space, intracellular space, and the majority (50\%) reaches the enterohepatic circulation. $E_{3}$ is conjugated mainly with glucuronic acid and to a lesser extent with sulfate in the maternal liver and then is excreted mainly in the conjugated form by the maternal kidney. $A$ portion of the $E_{3}$ conjugate passes from the maternal liver via the enterohepatic circulation into the gut. Hydrolysis of the conjugate by bacterial flora is essential for reabsorption of $\mathrm{E}_{3}$ and its return to the liver for reconjugation.

Maternal hepatic disease may impair conjugation. In obstructive gallbladder disease the enterohepatic circulation is disrupted and $\mathrm{E}_{3}$ will be lost in the feces.

$\mathrm{E}_{3}$ conjugates are finally excreted in the urine. Seriously impaired renal function will reduce this excretion and decrease the amount of estriol in the urine. Low $\mathrm{E}_{3}$ values also are found in certain types of congenital anomalies, particularly anencephaly, severe congenital heart disease, and Down's syndrome [11]. Certain drugs interfere with the $\mathrm{E}_{3}$ test and give spuriously low results: mandelamine, corticosteroids, and glucose in the urine causes partial distruction of $\mathrm{E}$ in acid hydrolysis. Administration of ampicillin decreases gut flora $[1,7,15]$. Willman and PUlKkinen [16] have demonstrated the lowering effect of ampicillin molecule in the enterohepatic circulation.

Urinary estriol measurements have many practical disadvantages: the inconvenience of a 24-hour collection of urine; errors will often be made in collecting the 24-hour urine specimen, and the considerable delay in obtaining the results. Consequently, acute changes in fetal condition may often be missed.

CAP is an enzyme of placental origin as proved also by us in a series of previous studies $[1,3,6]$. CAP is present in the maternal serum only during pregnancy, its level increasing with the gestation age, and afterwards decreases gradually, and not abruptly, disappearing 4 weeks after delivery and in puerperium [4]. The enzymatic level is not affected by antibiotic treatment.

As reported also by BUCHAN and KLOPPER [9], we have observed a sharp lowering of the urinary estriol level in women treated by ampicillin during the postpartum period, the level being of $1.62 \mathrm{mg} /$ $24 \mathrm{~h}$, as against $5.555 \mathrm{mg} / 24 \mathrm{~h}$, after $48 \mathrm{~h}$, in women not receiving antibiotic treatment, results in agreement also with those reported by CARPENTER [10]. This fact can be explained possibly by the lowering action of the antibiotic on the 
maternal estriol, and especially by the blocking effect of ampicillin on the enterohepatic circulation, which is the main compartment of the maternal body where $E_{3}$ is present in a proportion of $50 \%$. From our study it may be also concluded that CAP is not exposed to fluctuations of any kind, and is not influenced by the antibiotic treatment. Therefore, it is capable to demonstrate accurately the fetal well-being. It is worth-

\section{Summary}

In a group of 26 primiparae, 48 hours after cesarean section, we have examined the urinary estriol $\left(E_{3}\right)$ and serum cystine aminopeptidase (CAP). 13 patients received ampicillin treatment, and 13 patients did not. In the group of patients without antibiotic treatment the urinary estriol after $48 \mathrm{~h}$ reached an average value of $5.55 \mathrm{mg} / 24 \mathrm{~h}$. In the group of treated patients the drastic decrease of $E_{3}$ reached a mean value of $1.62 \mathrm{mg} / 24 \mathrm{~h}$. This fact may be explained by the arrest of the feto-placental inflow after delivery, and the blocking effect of the antibiotic on the

Keywords: Ampicillin, estriol, fetal well-being, oxytocinase. while noting that this test is easy to perform, rapid and not expensive, and does not necessitate a complicated instrumentation.

The examinations of the estriol, CAP, HPL, LAP levels are part of a complex examination necessary and useful in the assessment of the normal development of the pregnancy, which must be completed, if needed, by the bioelectrical methods. enterohepatic circulation, compartment which afford for $50 \%$ of the maternal circulating estrogen. From the present work it results that the determination of the serum CAP activity, which is not affected by antibiotic treatment, is an appropriate test for the assessment of the fetoplacental unit activity. It must be mentioned that all the biochemical tests complete one another and may have a decisive role in taking immediate obstetrical decisions, together with the additional fetal heart rate monitoring and oxytocin challenge test.

\section{Zusammenfassung}

Oxytocinase versus Östriol bei der Überprüfung der fetalen Versorgung

Wir bestimmten bei 26 Erstgebärenden 48 Stunden nach einer Sectio die Östriol( $\left.E_{3}\right)$-Ausscheidung im Urin und die Konzentration der Cystinaminopeptidase (CAP, spaltet Oxytocin) im Serum. 13 Patientinnen wurden mit Ampicillin behandelt, die anderen erhielten keine antiobiotische Therapie. In dieser Gruppe betrug die mittlere Östriolausscheidung im Urin nach 48 Stunden $5.55 \mathrm{mg} /$ $24 \mathrm{~h}$, während in der behandelten Gruppe die mittlere Östriolausscheidung im Urin bei $1.62 \mathrm{mg} / 24 \mathrm{~h}$ lag. Diese Werte können durch eine Hemmung des feto-plazentaren Durchstroms nach der Entbindung und durch den blockierenden Effekt der Antibiotika auf den enterohepatischen
Kreislauf erklärt werden. Dabei muß man bedenken, daß der enterohepatische Kreislauf als Kompartiment für ca. $50 \%$ der mütterlichen Östrogene fungiert. Wir schließen aus dieser Untersuchung, daß die Bestimmung der SerumCAP-Aktivität, die keiner Beeinflussung durch die antibiotische Therapie unterliegt, einen besseren Parameter zur Funktionsüberprüung der fetoplazentaren Einheit darstellt. Es soll erwähnt werden, daß alle biochemischen Tests einander ergänzen bzw. ihren Stellenwert haben und sie zusammen mit der Registrierung der fetalen Herzfrequenz und dem Oxytocin-Stimulationstest Entscheidungshilfen für das richtige geburtshilfliche Vorgehen geben können.

Schlüsselwörter: Ampicillin, fetale Versorgung, Oxytocinase, Östriol.

\section{Résumé}

Oxytocinase ou oestriol pour l'appréciation du bienêtre foetal

Nous avons examiné dans un groupe de 26 primipares, 48 heures après la césarienne l'Oestriol urinaire $\left(E_{3}\right)$ et la Cystine Aminopeptidase sérique (CAP). 13 patientes reçurent de ampicillines et 13 non. Les patientes sans antibiotiques atteignaient une moyenne dioestriol urinaire de $5,55 \mathrm{mg} / 24 \mathrm{~h}$. Chez les patientes sous ampicilline l'on observe une chute brutale de $\mathrm{l}^{\prime} \mathrm{E}_{3}$ avec une moyenne de $1,62 \mathrm{mg} / 24 \mathrm{~h}$. Ceci peut être expliqué par l'arrêt de l'apport feto-placentaire après l'accouchement et l'éffet bloquant de l'antibiotique sur la circulation entéro- 
hépatique, compartiment qui compte pour $50 \%$ de l'oestrogène maternelle circulante. Le présent travail montre que le détermination de l'activité de la CAP, qui n'est pas affectée par le traitement antibiotique, est un test approprié d'appréciation de l'activité de l'unité feto- placentaire. Il est à noter que l'ensemble des tests biochimiques se complètent et ont un rôle décisif dans la prise de conduites obstétricales immédiates, ensemble avec l'enrigistrement de la fréquence cardiaque foetale et le test à l'ocytocine.

Mots-clés: Ampicillinc, état foetal, ocytocinase, oestriol.

Acknowledgement: The author thanks Mrs. RUTH DON, from the Research Section of Kupat Holim Center for the statistical processing of data. He also thanks his collegues Dr. FELDBERG and Dr. MENKES for their great help in obtaining the specimens.

\section{Bibliography}

[1] ADLERCREUTZ, H., F. MARTIN, T. LEHTINEN, M. J. TIKKANEN, M. O. PULKKINEN: Effect of ampicillin administration on plasma conjugated and unconjugated estrogen and progesterone levels in pregnancy. Amer. J. Obstet. Gynec. 128 (1977) 266

[2] BLUM, M., S. WOLKOWISKY; R. MENACHE, I. HALBRECHT: Oxytocinase in normal and pathological pregnancies. Harefuah 81 (1971) 167

[3] BLUM, M., E. COHEN, F. SHABTAY, I. HALBRECHT: L'ocytocinase du liquide amniotique. Dosage et origine dans les grossesses normales et pathologiques. Rev. Fr. Gynec. Obstet. 70 (1975) 639

[4] BLUM, M., F. SHABTEI, I. HALBRECHT: Relationship between postpartum serum oxytocinase levels and afterpains. Harefuah 88 (1975) 316

[5] BLUM, M., P. SIROTA: Serum cystine aminopeptidase and leucine aminopeptidase activity in women with benign and malignant uterine and ovarian tumors. Isr. J. Med. Sci. 13 (1977) 875

[6] BLUM, M.: Comparative study of serum CAP activity during pregnancy in malformed and normal uterus. J. Perinat. Med. 6 (1978) 165

[7] BOEHM, F. H., D. L. DI PIET RO, D. A. Goss: The effect of ampicillin administration on urinary estriol and serum estradiol in the normal pregnant patient. Amer. J. Obstet. Gynec. 119 (1974) 98

[8] BROWN, J. B., R. D. BULBROOK, F. C. GREENWOOD: An additional purification step for a method for estimating oestriol, oestrone and oestradiol - 17 in human urine. J. Endocrinol. 16 (1957) 49
[9] BUCHAN, P. C., A. KLOPPER: Enterohepatic circulation of oestriol: a study of the effects of ampicillin on plasma oestriol levels. Brit. J. Obstet. Gynaec. 86 (1979) 713

[10] CARPENTER, C. W.: Urinary estrogen excretion in the puerperium. Amer. J. Obstet. Gynec. 99 (1967) 303

[11] JORGENSEN, P. I., D. TROLLE: Low urinary oestriol excretion during pregnancy in women giving birth to infants with DOWN's syndrome. Lancet II (1972) 782

[12] KLOPPER, A., P. BUCHAN, G. WILSON: The plasma half-life of placental hormones. Brit. J. Obstet. Gynaec. 85 (1978) 738

[13] LUUKKAINEN, T.: Identification and determination of estrogens in various biological materials in pregnancy. Ann. Clin. Res. 2 (1970) 365

[14] RADO, A., C. D. CRYST LE, J. D. TOWNSLEY: Concentration of estrogens in maternal peripheral plasma in late pregnancy, during labor and post partum. J. Clin. Endocrinol. Metab. 30 (1970) 497

[15] TRYBUCHOWSKI, H.: Effect of ampicillin on the urinary output of steroidal hormones in pregnant and nonpregnant women. Clin. Chim. Acta 45 (1973) 9

[16] WILlmaN, K., M. O. PUlKKINEN: Reduced mamaternal plasma and urinary estriol during ampicillin treatment. Amer. J. Obstet. Gynec. 109 (1971) 893

Received April 17, 1980. Revised August 19, 1980. Ac cepted November 7, 1980.

Dr. M. Blum

Department of Obstetrics and Gynecology Hasharon Hospital

Petah-Tiqva, Israel 